\title{
Towards a scientific status for micromolecular Systematics
}

\author{
Otto R. Gottlieb ("*)
}

\begin{abstract}
While different biosynthetic groups of secondary metabolites (micromolecules) rarely accumulate in the same plant species, one such group may replace another in morphologically related taxa. The use of micromolecules as general systematic markers of the piant kingdom thus requires unifying postulates concernıng their evolution patterns. Two such postulates - contraction of the shikimate pathway and blocking of oxidative enzymes - are illustrated with the aid of systematic considerations on the genera Aniba (Lauraceae) and Derris-Lonchocarpus (Leguminosae) which involve besides chemistry, morphology, ecology and geography. Extrapolation of the principles applied in these examples to the entire plant kingdom seems possible, an important fact, due to the ecoiogical implications of micromolecules. In this sense, the paper opens the way, rather than simply to a more "natural" classification, to an information retrieval device of ecologically relevant facts about plants.
\end{abstract}

\section{INTRODUCTION}

The evolutionary classification of plants is endowed with predictive value (Cronquist, 1968), i.e. a better than random chance exists for information on certain characters of as yet unstudied taxa to fall into the pattern which has been established for these characters by the study of a relatively limited number of taxa. The closer the evolutionary relationship of the taxa, the higher the chance for reasonable predictions. So far, so good; unless you have recognized the $\mathrm{x}$-part of the equation 1 just mounted, namely the pattern-concept. It is, of course, not possible to extrapolate experimentally determined chemical characters until the patterns of chemical evolution are ennounced, until the chemical phenomena which accompany development of lineages become known.
We know by now about patterns of macromolecular evolution and appreciate that nucleic acid and protein (cytochrome c, ferredoxín, plastocyanin, hemoglobin) data (Smith, 1976) are the best, if not sole, unifying themes bridging the diversity of organisms. But can micromolecules be used in a similar way? The answer to this question is no if we think of each biogenetic group of metabolites in isolation. To quote only examples from our own work, benzylisoquinolines (Rezende et al., 1975), indoles (Cagnin et al., 1977), quinolizidines (Salatino \& Gottlieb, 1980), quinolones (Gottlieb et al., 1980) and a few other classes of alkaloids (Gomes \& Gottlieb, 1980 ), as well as coumarins (Gottlieb et al., 1980), flavonoids (Cagnin \& Gottlieb, 1978; Gomes et al., 1980), iridoids (Kaplan et al., 1980), xanthones (Rezende \& Gottlieb, 1973; Kubitzki et al., 1978) are usually employed as systematic markers for particular plant taxa. It has been established, however, that different groups rarely accumulate, i.e. are subject to structural variation, in the same species (Gottlieb, 1980) and that, indeed, one group may replace another in morphologically related taxa (Gottlieb \& Kubitzki, 1980a). Let us accept this as evidence that these groups perform anologous functions, say defence, attraction of pollinators, and set out to find a common characteristic capable of measuring evolutionary advancement of a metabolite irrespective of the biogenetic group to which the metabolite belongs. This means, of course, that we will have to shift emphasis from the structure of accumulated molecules to alterations of biosynthetic pathways. Although this requirement has been clearly stated years ago (Birch, 1963), its recognition was not im-

$\left({ }^{\circ}\right)$ - Half-Hour Plenary Lecture given at the 12th IUPAC Symposium on the Chemistry of Natural Products, Tenerife, Canary Islands, Sept. 21-27, 1980. A travel grant by Conselho Nacional de Desenvolvimento Cientifico e Tecnológico (CNPq), Brasil, is gratefully acknowledged.

$($ (*) - Instituto de Química, Universidade de São Paulo, São Paulo. 
mediately helpful. No procedures existed to assess the significance of such alterations in connection with plant evolution (Birch, 1973).

The natural products chemist knows of only one way to deduce biosynthetic correlations: inspect the structure of micromolecules and analyse their common features in relation to natural occurrence. In doing this we stumbled upon several conspicuous trends of micromolecular evolution. Interpreted in terms of basic principles they may prove of value in elevating micromolecular systematics from an old art into a scientific discipline.

The first principle (Fig. 1, top) states that evolution of the primary precursors (from which biogenetic groups of secondary metabolites are derived) proceeds by blocking of reaction steps. Such blocking leads to new chemical lines. Within each line evolution of the metabolites belonging to biogenetic groups proceeds by diversification ('). The second principle (Fig. 1, bottom) states that evolution of micromolecules proceeds by oxidation. The relatively highly oxidized compounds characterize new chemical lines. Within each line evolution proceeds by deoxygenation.

In the following sections, the relevance of these principles is discussed with the aid of two examples, the systematics of Aniba and of Derris-Lonchocarpus, genera of our south America flora. We have commented on these topics in papers (resp. Gottlieb \& Kubitski, 1980a, b; Gomes et al., 1980) which should be consulted inclusively for references to the voluminous literature on the chemical composition of species.

\section{MICROMOLECULAR EVOLUTION IN ANIBA}

The chemistry of 18 out of the 41 recognized Aniba species (family Lauraceae) (Kubitzki, 1980) is fairly well known. In essence, their trunk wood contains propenylphenols (1) and allylphenols (2), precursors to neolignans belonging to several constitutional and configurational types which may be biosynthetically simple $(3-6)$ or derived $(7-9)$ (Fig.

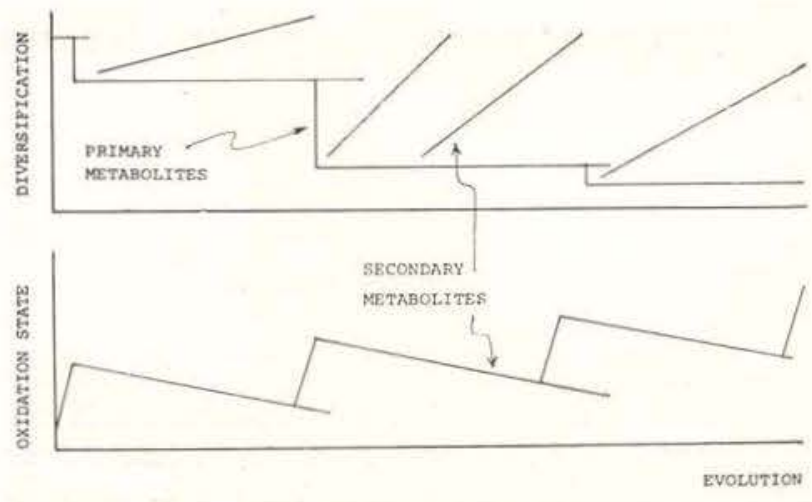

Fig. 1 - Basic concepts of micromolecular evolution.

2); pyrones, again biosynthetically simple (10, 12) or derived $(11,13)$, and benzophenones (14) (Fig. 3); benzyl benzoates (15), benzylisoquinoline alkaloids (16) and sporadically flavonoids, a queer alkaloid (17) and linalool (18) (Fig. 4). With the exception of this monoterpene, all these biogenetic groups of micromolecules stem from a primary biosynthetic pathway linked to shikimic acid (Fig. 5). The benzylisoquinolines and the benzyl benzoates are not only ubiquitous, but also practically invariant in all species, and hence of value only in revealing ancestry, i.e. in situating the genus within the family Lauraceae, a topic which was discussed elsewhere (Gottlieb, 1972, 1980; Ferreira et al., 1980). Others, however, such as the neolignans, the pyrones and the benzophenones are restricted to particular species listed in Table 1 in groups according to chemical composition. A neat dichotomy is seen to exist in Aniba between neolignan vs. pyrone containing species. Not once have both types of compounds yet been reported for a single species.

In my experience such switch-overs are reasonably general phenomena and chemists who tried to classify taxons by presence/ /absence of chemical characters have often seen their results under fire from morphologists (cf. e.g. Mabry, 1974). This is where our principles of micromolecular systematics come in. According to the first principle, blocking of reaction steps in the shikimate

(1) - This corollary of the first principle was formerly designated seçond principle (Gottlieb, 1980). 
<smiles>CC=CC=[Te]</smiles><smiles>C=CC[C@]12C=C(OC)C(=O)C=C1OC([Ga])[C@@H]2C</smiles>

1

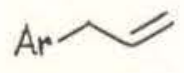

$\underline{2}$

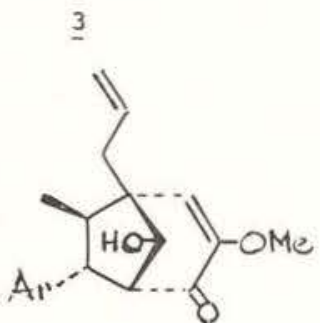

4<smiles>[CH][C@@H]1OC2=CC(=O)C(OC)=C[C@]2(CC=C)[C@@H]1C</smiles>

$\stackrel{5}{\sim}$

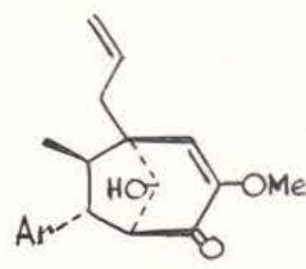

6<smiles></smiles>

?<smiles>C=CC[C@]1([C@@H](C)C(=O)O)C[C@H](OC)C=CC1=O</smiles>

$\stackrel{8}{2}$<smiles>[CH]C1OC2(O)C(=O)C=CC[C@]2(CC=C)C1C</smiles>

9

Fig. 2 - Main types of neolignans of Aniba species

pathway would imply the use of cinnamates rather than of propenylphenols as biosynthetic starting materials. Application of the principle to the case of Aniba (Fig. 5) thus suggests the evolution of the propenylphenol derived neolignans into the cinnamate derived pyrones, benzophenones and flavonoids, and assigns a more primitive position in the evolutionary history of the genus to the neolignan than to the pyrone containing species.

According to the corollary of the first principle, evolution of micromolecules in a biogenetic group involves substitutional, configurational and/or skeletal diversification Replacement of the neolignans of types $3-6$ by $7-9$, as well as of the pyrones of types 10 by 11 and of types 12 a by 13 or addition of anibine (12b) and benzophenones (14), requires skeletal diversification through expansion of reaction pathways. Application of the corollary to the case of Aniba thus warrants the listing of the species within each of the three groups, the neolignan and the two pyrone ones, in order of evolutionary advance as shown in Table 1.

How does this chemical classification correlate with morphology (Table 2)? Flora! structure suggests a subdivision of the genus in two groups according to the opening modes of the valves of the anther cells of the stamens. The structure of the lower leaf epidermis and wood anatomy also seem to be characters of classificatory importance.

What we have learnt so far is that the evolutions of chemical, floral, vegetative and histological characters proceed as general trends, in parallel. Since the differentiation of these characters is largely independent, it 
TABLE 1 - Chemical characteristics of 18 out of 41 recognized Aniba species

\begin{tabular}{|c|c|c|c|c|c|c|c|c|}
\hline & Species & $\begin{array}{c}\text { Allyl. } \\
\text { phenols }\end{array}$ & Neolignans & & es & $\begin{array}{l}\text { Benzo- } \\
\text { phenones }\end{array}$ & $\begin{array}{c}\text { Essential } \\
\text { oils }\end{array}$ & $\begin{array}{l}\text { Alka- } \\
\text { loids }\end{array}$ \\
\hline 1 & A. affinis & 2 & 3 & & & & $15 \mathrm{r} a, b$ & \\
\hline 12 & A. burchellii & $\underset{2}{3}$ & $\underset{\sim}{3}$ & & & & $15 \mathrm{a}, \mathrm{b}$ & 16 \\
\hline 9 & A. williamsii & & $\underset{\sim}{5}$ & & & & $15 \mathrm{\sim} a, \mathrm{~b}$ & $\underset{\sim}{16}$ \\
\hline 5 & A. terminalis & & $\underset{\sim}{5}$ & & & & $15 \mathrm{~N}, \mathrm{~b}$ & $1 \underset{\sim}{6}$ \\
\hline 3 & A. Iancifolia & $\underset{\sim}{2}$ & $\underset{\sim}{7}$ & & & & & \\
\hline 17 & A. megaphylla & & 8 & & & & & \\
\hline 41 & A. ferrea & & $\stackrel{2}{2}$ & & & & & \\
\hline 40 & A. canelilla & 2 & & 10 & $12 a$ & & $\underset{\sim}{15} \mathrm{a}, \mathrm{b}, \mathrm{c}, \mathrm{d}$ & \\
\hline 22 & A. kappleri & & & 12 & & & & $\underset{\sim}{16}$ \\
\hline 28 & A. panurensis & & & 10 & $12 \mathrm{a}$ & & $15 \mathrm{~b}$ & \\
\hline 37 & A. heringerii & & & $\frac{10}{2}$ & $12 \mathrm{\sim}$ & & $15 \mathrm{~N} a \cdot \mathrm{b}$ & \\
\hline 38 & A. firmula & & & $\underset{\sim \sim \sim}{10}$ & $12 \mathrm{\sim} a$ & & $15 \mathrm{\sim} a, \mathrm{~b}$ & \\
\hline 39 & A. cylindriflora & & & $\underset{\sim}{11}$ & & & $\underset{\sim}{15} \mathrm{a}, \mathrm{b}$ & \\
\hline 36 & A. permollis & 2 & & $\underset{\sim}{11}$ & & & & $1 \underset{\sim}{16}$ \\
\hline 33 & A. parviflora & & & & $12 \mathrm{~N} a, b$ & & $15 \mathrm{~N} a$ & \\
\hline 29 & A. rosaeodora & & & & $12 \mathrm{a}, \mathrm{b}$ & ${ }_{\sim}^{14} \sim \mathrm{a}, \mathrm{b}$ & $15 \mathrm{\sim} a, \mathrm{~b}$ & \\
\hline 27 & A. santalodora & & & & $12 \mathrm{a}$ & & 18 & $1 \underset{2}{6}$ \\
\hline 39 & A. coto & 2 & & & $\underset{\sim}{\sim}, \quad 12 \mathrm{~d}$ & $14 \mathrm{a}$ & $\underset{\sim \sim}{15} \mathrm{a}$ & 27 \\
\hline
\end{tabular}

cannot be synchronous and intermediate forms with some primitive and some advanced characters must occur in all taxons. The assumption that morphology will correlate with chemistry has thus only a reasonable chance (in Aniba 13/18) to be correct, and it would be wise to look for other, again independent, evidence to strengthen the predictive value of the analysis.

That such evidence may be inherent to ecogeographical phytochemistry, a discipline for which we recently formulated basic tenets (Gottlieb et al., 1980), can be inferred from the distribution of Aniba species registered in Table 2. Surely you recognize the accumulation of central Amazonian species on top of the list, the existence of extra Amazonian species towards the middle and the incidence of relatively widespread species towards the botton as an indication for the existence of general distributionai trends. According to the firt tenet, plant populations possess a center of irradiation where they are endowed with a biosynthetically simple chemistry. Conquest of new regions is conditioned by the constitutional or configurational diversification of allelochemics (micromolecules) through gradual acquisition of new biosynthetic pathways. In the case of Aniba, central Amazonian stock appears to have spread towards the periphery of Amazonia diversifying its neolignan chemistry and into the regions beyond replacing it by pyrone chemistry. In this sense then the outward spread is postulated to have involved A. affinis, A. burchellii (Fig. 6) $\rightarrow$ A. terminalis, A. williamsii (Fig. 7) $\rightarrow A$. megaphylla (Fig. 8). At some point of this evolutionary dispersal, the switch-over from neolignans to pyrones must have taken place and resulted in the development of two parallel, peripheral lines. One, with pyrones of type 10 , is represented by $A$. kappleri and $A$. heringerii $\rightarrow A$. firmula (Fig. 9). The other, with pyrones of type 12 , is represented by $A$. rosaeodora sensu Ducke (i.e. from Guiana) and A. coto (Fig. 10).

According to the second tenet, the geographical development of natural products chemistry is directional. At the fringes of a species habitat, slightly different metabolites may be produced, together with the old ones, adapting the species to the new conditions. Dispersal from the fringe back into the territory occupied 
<smiles>COc1cc(/C=C/[13CH3])oc(=O)c1</smiles>

$\underset{\sim}{10}$<smiles>Cc1cc(Br)oc(=O)c1</smiles>

$12 \mathrm{a} \mathrm{Ar}=\operatorname{ary} 1$

$12 \mathrm{~b}$ Ar $=$ B-pyridy 1<smiles>O=c1cccc(/C=C/[AlH2])o1</smiles>

$\underset{\sim}{11}$<smiles>O=c1cccc([TlH2])o1</smiles>

$\underset{\sim}{13}$<smiles>[R]Oc1cc(OC)cc([R])c1C(=O)[In]</smiles>

$\underset{\sim}{14} \underset{\sim}{\mathrm{a}} \mathrm{Ar}=\operatorname{aryl}$ $\underset{\sim \sim}{14 \mathrm{~b}}$ Ar $=$ B-pyridy 1

Fig, 3-Main types of cinnamate-acetate derived metabolites of Aniba species

by the old and very similar species, however, is not favoured since for ecologically associated sympatric species chemical diversity is advantageous if not mandatory, and directionality of migration results. In the case of Aniba, chemically similar species are indeed allopatric (Figs. 6, 11). Once the chemical composition of the lineage, however, has been altered significantly (by acquisition of pyrones), possibly at or beyond the limits of the Amazon basin, reversal of the migratory direction would have been an allowed process since it leads to the co-existence of species characterized by considerably diverse chemical compositions. The neolignan-free chemistry of peripheral Aniba species thus made their re-entry into Amazonia possible. This was achieved in the 10-pyrone lineage by $A$. panurensis (Fig. 11) and $A$. canelilla (Fig. 12) and climaxed by the again central Amazonian $A$. cylindriflora and A. permollis (Fig. 13) with pyrones of type 11; and in the 12-pyrone lineage by $A$. parviflora and $A$. duckei Kosterm. (now included in $A$. rosaeodora) and climaxed in the again central Amazonian A. santalodora (Fig. 14).

Thus, although in 5 out of the 18 experimental cases of Table $2(12,17,41,40,22)$ the

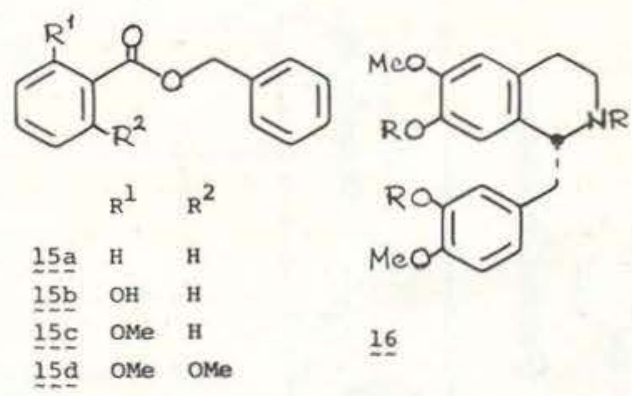<smiles>C=CC(C)(O)CCC=C(C)C</smiles>
18<smiles>COc1ccc2[nH]c3c(Cc4ccc(O)cc4)nccc3c2c1</smiles>

Fig. 4-Selected types of metabolites of Aniba species 
TABLE 2 - Chemical, morphological, histological and geographical characteristics of 18 out of 41 recognized Aniba species.

\begin{tabular}{|c|c|c|c|c|c|c|c|c|c|c|c|c|c|}
\hline & & Species & & & $\begin{array}{l}\text { Che: } \\
\text { charact }\end{array}$ & $\begin{array}{l}\text { ical } \\
\text { ristics }\end{array}$ & & & $\begin{array}{l}\text { her cells of } \\
\text { er stamens }\end{array}$ & $\begin{array}{l}\text { Leaf under- } \\
\text { surface }\end{array}$ & $\begin{array}{l}\text { Wood } \\
\text { anatomy }\end{array}$ & $\begin{array}{l}\text { Geographical } \\
\text { Amazonia }\end{array}$ & $\begin{array}{l}\text { distribution } \\
\text { Periphery }\end{array}$ \\
\hline 1 & A. & affinis & 3 & 4 & & & & & introrse-latrorse & smooth & Aniba-type & Negro & - \\
\hline 12 & A. & burchelli & 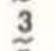 & $\stackrel{4}{2}$ & & & & & $\cdot$ & papillose & $\cdot$ & Mad., Ama. & - \\
\hline 9 & A. & williamsii & $\widetilde{\mathbf{5}}$ & $\tilde{\sigma}$ & & & & & $\cdot$ & smooth & • & Lower Negro & Guiana \\
\hline 5 & A. & terminalis & $\mathbf{5}$ & $\underline{6}$ & & & & & - & $\cdot$ & - & Sol., Mad., Ama. & - \\
\hline 3 & A. & lancifolia & $\tilde{\tilde{7}}$ & & & & & & $\cdot$ & - & - & Lower Negro & - \\
\hline 17 & A. & megaphylla & $\tilde{8}$ & & & & & & strictly introrse & $\cdot$ & • & Neg., Sol., Ama, & Gulana \\
\hline 41 & A. & ferrea & $\tilde{2}$ & & & & & & $\cdot$ & $\cdot$ & Licaria-type & Lower Negro & - \\
\hline 40 & A. & canelilla & & & $11 a$ & $12 \mathrm{Na}$ & & & - & " &. & Mad., Neg., Ama. & Gul., Orinoco \\
\hline 22 & A. & kappleri & & & $11 a$ & $2 \approx$ & & & * & • & Aniba-type & $\rightarrow$ & Gui., Orinoco \\
\hline 28 & A. & panurensis & & & $11 a$ & $12 \mathrm{a}$ & & & " & papillose & $\cdot$ & $\begin{array}{l}\text { Mad., Sol., Negr., } \\
\text { Tap., Ama. }\end{array}$ & Guiana \\
\hline 37 & A. & heringeril & & & $11 \mathrm{a}$ & $12 a$ & & & - & $\cdot$ & - & - & Central Plat. \\
\hline 38 & A. & firmula & & & $1 \underset{\sim}{1} \mathrm{a}$ & $\tilde{1}_{\sim}^{2} \mathrm{a}$ & & & $\cdot$ & * & $\cdot$ & - & Atlantic Coast \\
\hline 35 & A. & cylindriflora & & & $\tilde{1} \tilde{\sim} \mathrm{b}$ & & & & " & " & - & Mad., Sol., Negr. & - \\
\hline 36 & A. & permollis & & & $\tilde{1} \tilde{\sim} \mathrm{b}$ & & & & " & $=$ & - & Solimōes & Guiana \\
\hline 33 & A. & parviflora & & & & $12 a$ & 13 & & - & 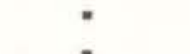 & & Mad., Tap., Ama. & Guiana \\
\hline 29 & A. & rosaeodora & & & & $12 \mathrm{\sim}$ & 13 & 15 & - & • & - & $\begin{array}{l}\text { Sol., Neg., Ama., } \\
\text { Toc. }\end{array}$ & Guiana \\
\hline 27 & A. & santalodora & & & & $12 \mathrm{\sim} a$ & & & $\cdot$ & - & - & Lower Negro & $\rightarrow$ \\
\hline 39 & A. & coto & & & & $\tilde{1} \tilde{\sim} \tilde{\sim} b$ & $\underset{\sim}{13}$ & 15 & * & • & • & - & Andes \\
\hline
\end{tabular}


three morphological characters give conflicting evidence, a reasonable decision concerning the probable chemical composition can be reached even here in 4 cases by consideration of the geographical distribution (e.g. A. ferrea is central Amazonian and thus should indeed contain neolignans; $A$. canelilla is inclusively peripheral and thus should indeed contain pyrones). A wrong forecast would be given only for A. megaphylla (a significant result in view of the high specialization of its neolignan chemistry). The reliability of the chemical inventory in the Aniba case thus would attain $17 / 18$ or $94 \%$.

MICROMOLECULAR EVOLUTION IN DERRISLONCHOCARPUS

All flavonoids which have so far been reported for species of the tribe Tephrosieae (family Leguminosae), to which the genera Derris and Lonchocarpus belong (Polhill, 1980), were classified into structural types, arranged and codified according to their biosynthetic relationship (Fig. 15). Considering the compo- sition of the species, characterized by the number of representatives of each structural type expressed percentually in relation to the total number of flavonoids, several neatly circunscribed clusters of Derris (Table 3) and Lonchocarpus (Table 4) species can be discerned. The direct application of micromolecular data thus does not provide evidence for infra-generic unity (a concept which is wholly derived from morphological criteria), and must be even less reliable in the differentiation or amalgamation of the two genera (a controversial botanical problem, cf. e.g. Polhill, 1971, vs. Geesink, 1980). There is, furthermore, no clearcut correspondence between the traditional morphological subgeneric groups (Phacelanthus and Lonchocarpus) and these chemical clusters. So either secondary metabolites are poor systematic markers or we overlooked information contained in the biogenetic map (Fig. 15).

This indicates formation, from an identical cinnamatetriacetate precursor, initially of stilbenes (1) and chalcones (2). From here on the reactions are mostly oxidative processes.

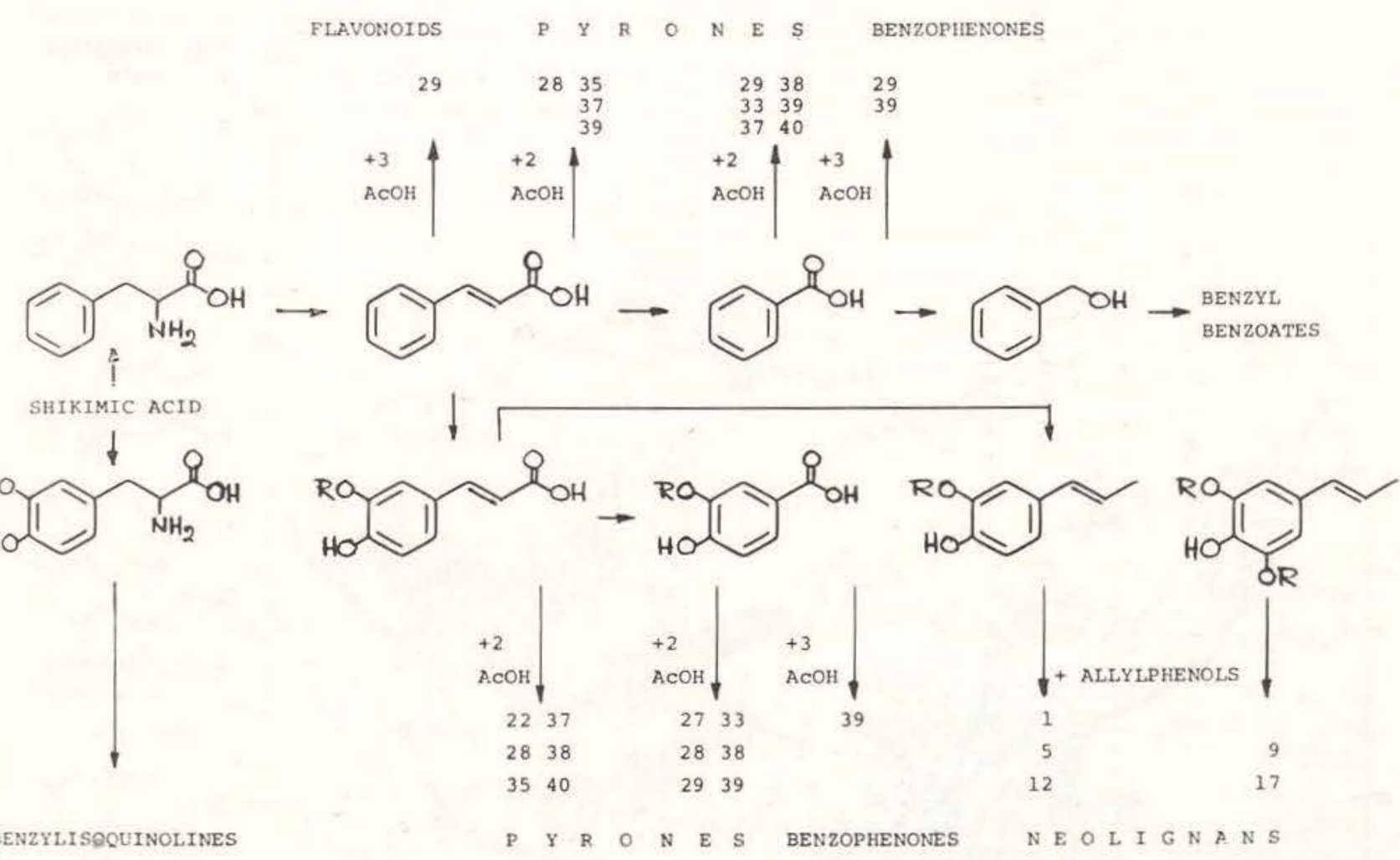

Fig. 5 - Metabolic pathways to classes of compounds of Aniba species indicateb by numbers (for key see Table 1) 

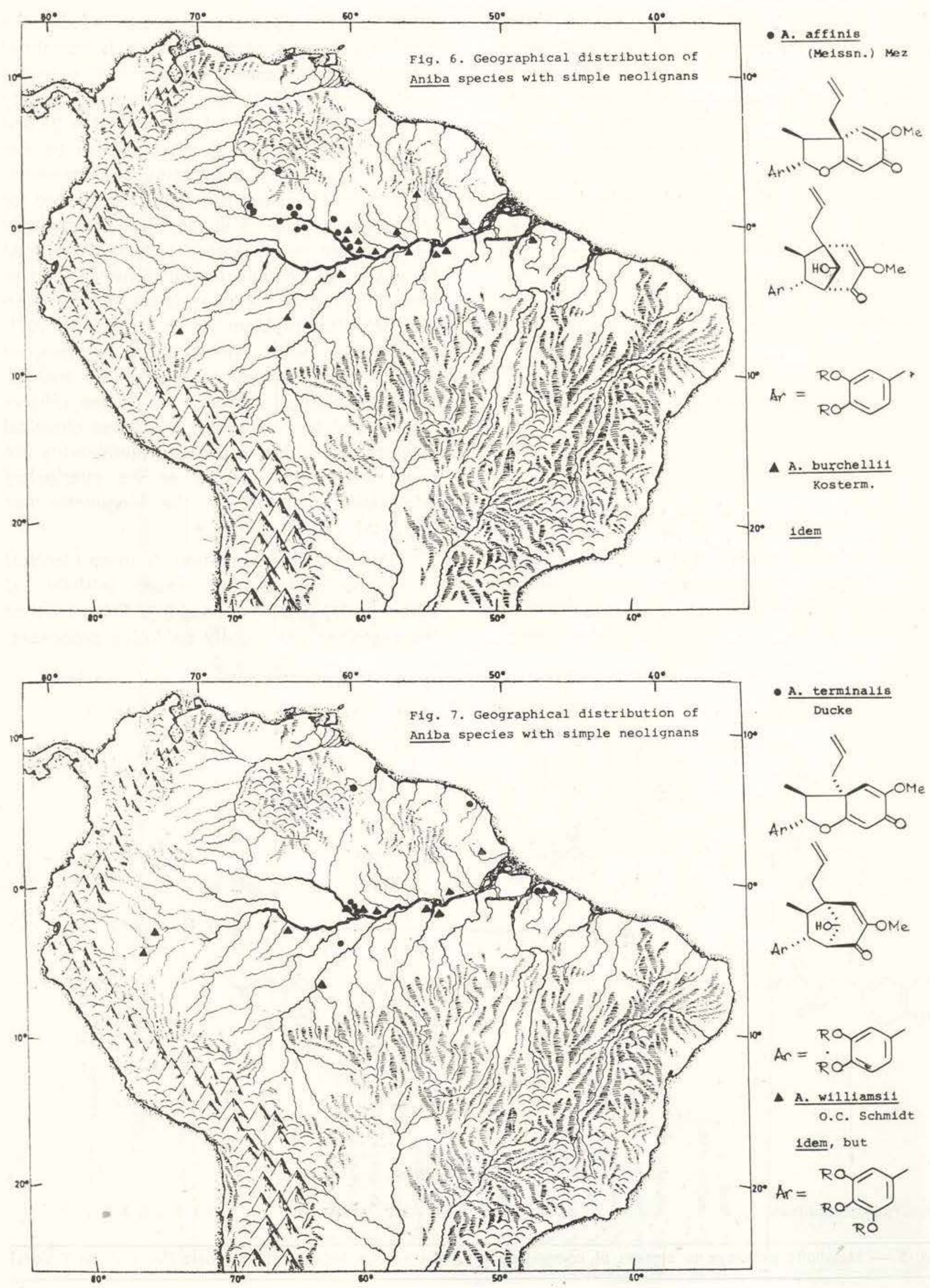

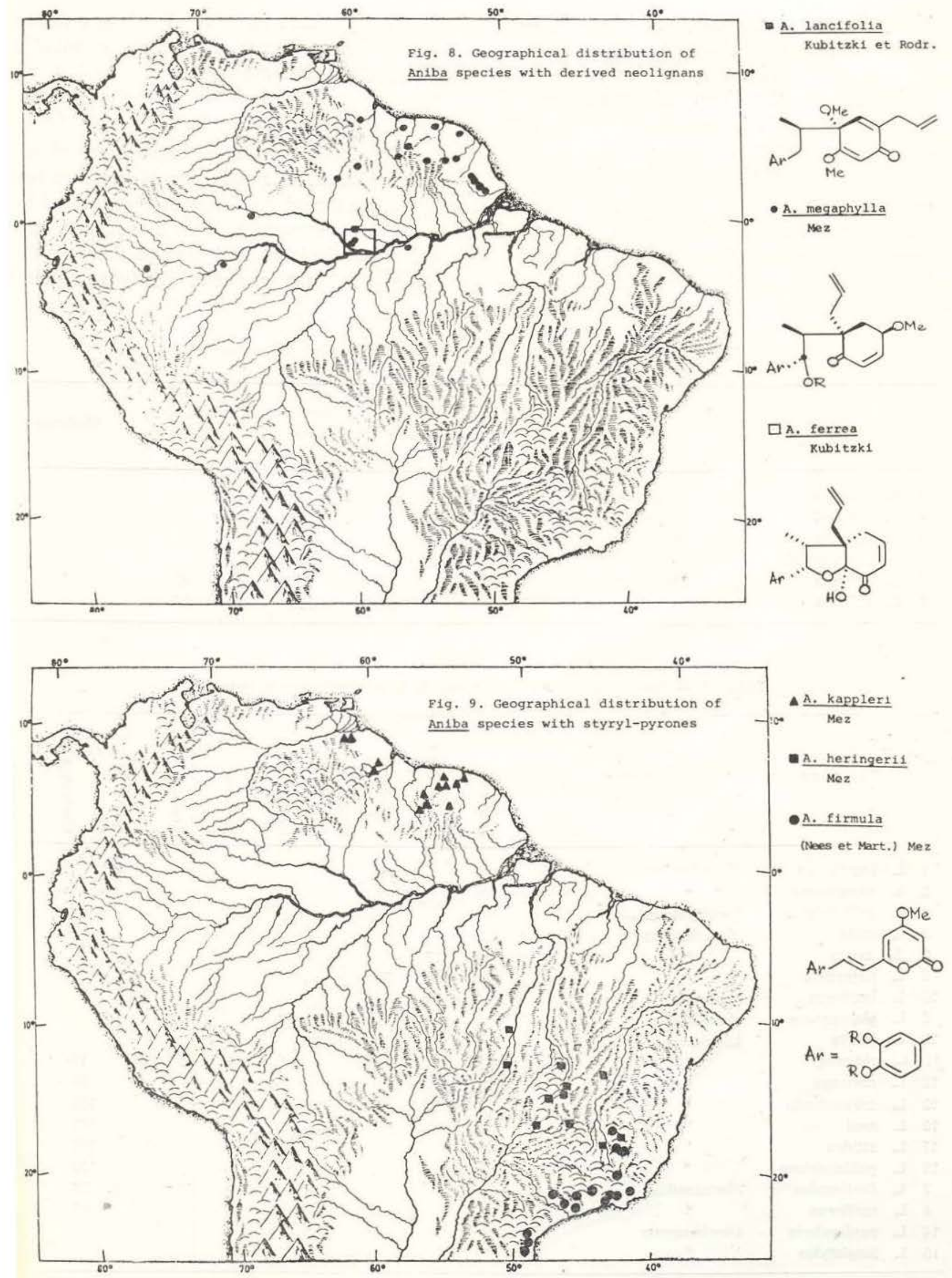

Towards... 
The presence of a para-hydroxyl on ring B of the chalcone is essential for the rearrangement to isoflavones and the cyclization to aurones. Reduction, in the form of elimination of chelated hydroxyls is thought to be the final step in all sequences.

The overwhelming majority of stilbenes and flavonoids from Tephrosieae sustains mevalonate derived $\mathrm{C}_{5}$-chains in form of unmodified or oxidatively modified prenyls. The incidence of the latter is higher in flavonoids whose formation involves oxidative steps (Fig. 16). Thus the redox potential of the general enzyme system in Tephrosieae must be relevant in determining the nature of the accumulated metabolites.

An indirect relative expression of the redox potential for each species was derived by the means of the "oxidation" values of the contained compounds. For a flavonoid this value is calculated assigning to the primitive stilbene (1) and chalcone (2) types 0 points

TABLE 3 - Percentual number of flavonoids from Derris species

\begin{tabular}{|c|c|c|c|c|c|c|}
\hline & Species & Groups & $\begin{array}{l}\text { Rote. } \\
\text { noids }\end{array}$ & $\begin{array}{l}\text { Isofla- } \\
\text { vans }\end{array}$ & $\begin{array}{l}\text { 4-OH-3-Ph- } \\
\text { coumarins }\end{array}$ & Chalcones \\
\hline 3 & D. ferruginea & Dipteroderris & 100 & & & \\
\hline 4 & D. trifoliata & Derris & 100 & & & \\
\hline 2 & D. elliptica & Paraderris & 100 & & & \\
\hline 1 & D. malaccensis & $"$ & 86 & 14 & & \\
\hline 6 & D. scandens & Brachypterum & 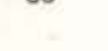 & 57 & 43 & 7 \\
\hline 5 & D. robusta & $\dddot{n}$ & & 56 & 37 & \\
\hline
\end{tabular}

TABLE 4 - Percentual number of flavonoids from Lonchocarpus species

species

Groups

\begin{tabular}{|c|c|c|c|c|c|c|c|c|c|}
\hline $\begin{array}{l}\frac{n}{0} \\
\frac{0}{0} \\
\frac{0}{0}\end{array}$ & 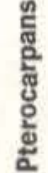 & 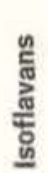 & 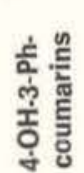 & 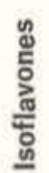 & 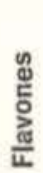 & 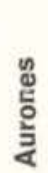 & $\begin{array}{l}\frac{\omega}{0} \\
\frac{0}{0} \\
\text { 은 }\end{array}$ & 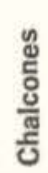 & 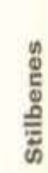 \\
\hline
\end{tabular}

1 L. Iongifolius

2 L. spruceanus

9 L. unifoliolatus

4 L. utilis

3. L. urucu

6 L. negrensis

19 L. laxiflorus

5 L. glabrescens

10 L. mollis

11 L. obtusus

12 L. sericeus

13 L. eriocarinalis

16 L. xuul

17 L. nitidus

18 L. guilleminiana

7 L. floribundus

8 L. rariflorus

14 L. peninsularis

15 L. longistylus

Phacelanthus
Lonchocarpus
Phacelanthus
Paniculati
Phacelanthus
Lonchocarpus
"
$"$
"
Phacelanthus
Lonchocarpus
"

100

100

100

100

83

$\begin{array}{ll}17 & \\ 50 & 50 \\ 50 & 50\end{array}$

$50 \quad 50$

$50 \quad 50$

$\begin{array}{llll}11 & 45 & 33 & 11\end{array}$

$33 \quad 67$

100

100

100

100

$\begin{array}{ll}75 & 25\end{array}$

$67 \quad 33$

100

100 

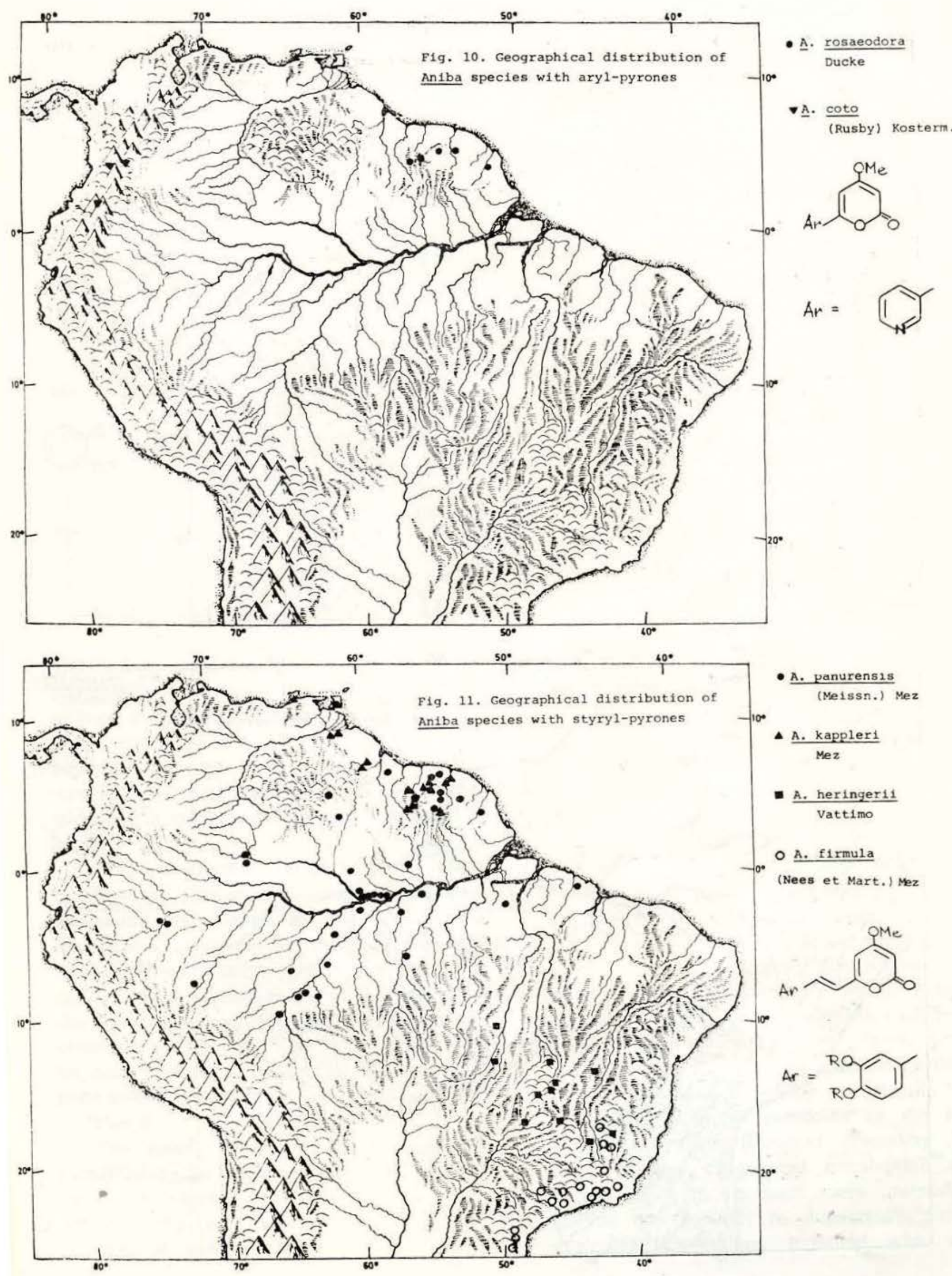

Towards... 

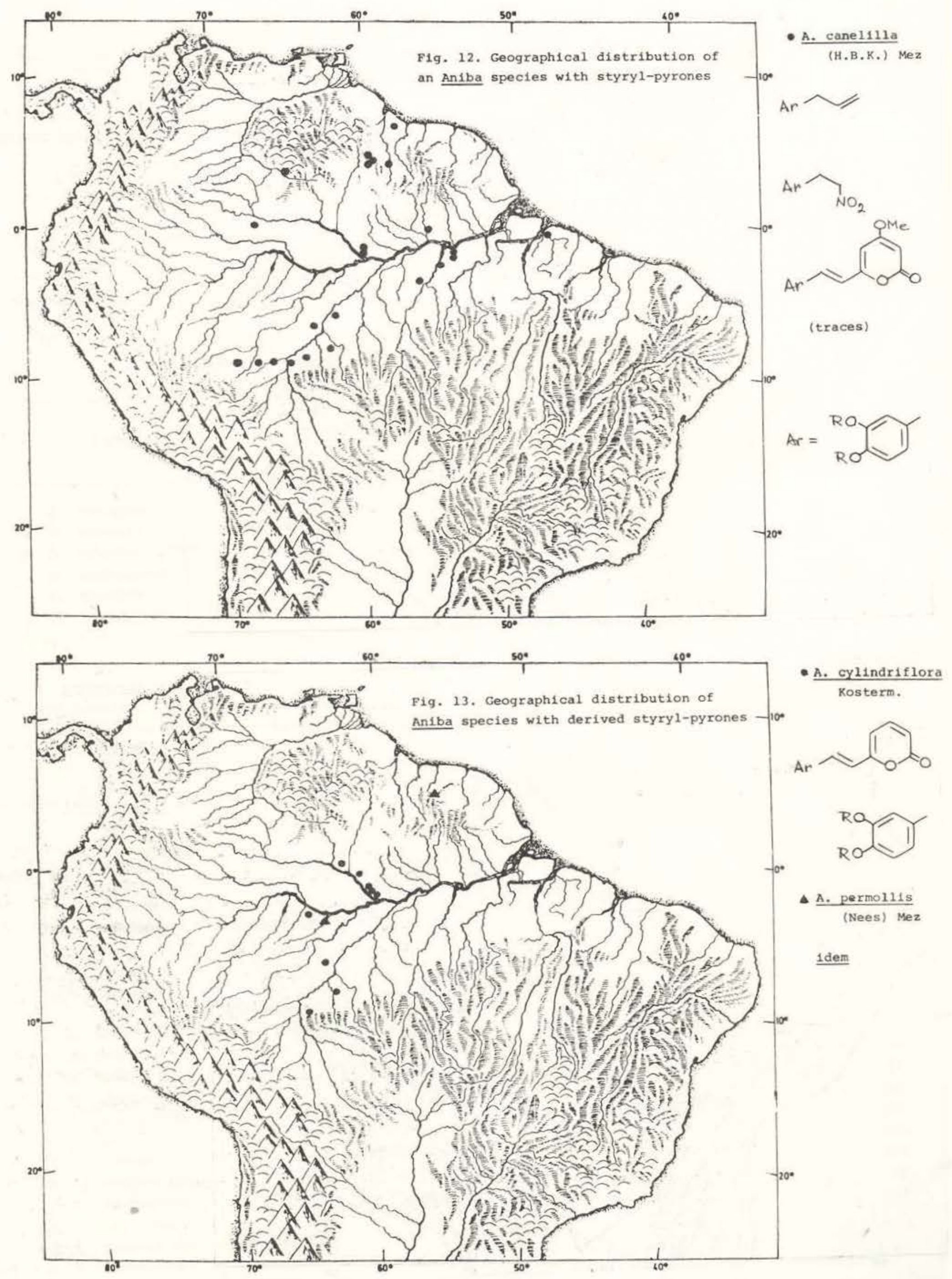


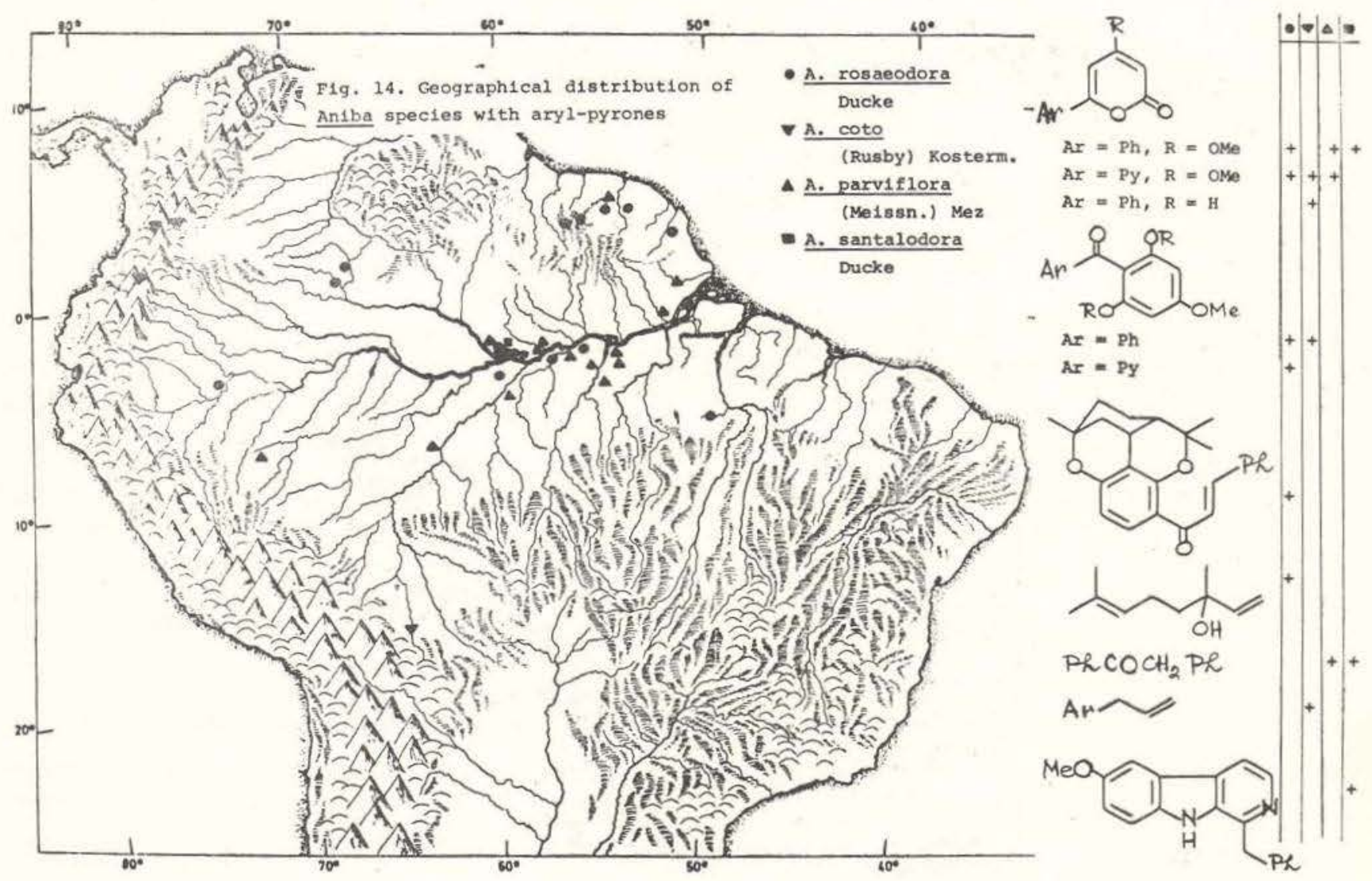

and adding or subtracting single points respectively for each oxidation or reduction step, defined in Fig. 15, necessary to arrive at the given structural type. In the particular compound this type may have undergone secondary modifications which are evaluated by further additions or subtractions of points as listed in Table 5

A further reaction, which determines the direction of a reaction sequence and thus influences the nature of the accumulated metabolites, concerns $\mathrm{O}$-methylation. The relative efficiency of the pertinent enzyme system can again be expressed for each species by the means of the "methylation" values of the contained compounds. This value is calculated for each compound by adding the pertinent point values for methoxyls and hydroxyls listed in Table 6.

The mean "oxidation" vs. "methylation" $(\mathrm{O} / \mathrm{M})$ values for flavonoids in Derris and Lonchocarpus species are plotted in Fig. 17. Although the plot shows several disjunct clusters of points, their location along a straight line conveys a feeling of continuity. The correlation of oxidizing and methylating power is not too surprising for reasons of the well known instability of phenolic substrates in oxidizing media.

Superposition of the chemical gradient on the general characteristics of the Derris-Lonchocarpus complex of species (Fig. 17) provides clues to their evolutionary history. This should have started in south-east Asia with species (numbered 1-4) associated with the Derris group (marked 0 ). At the time of their dispersal a humid tropical land-bridge must have extended to Amazonia where present day species (1-4) of the Phacelanthus group (-) are again rotenoid bearing forest lianes with clustered flowers. Comparison of these Asian and American groups reveals the loss of 5-hydroxylation of rotenoids as the sole variation of their flavonoid chemistry. The trend to less oxygenated metabolites also occurs, although in a much more pronounced fashion due possibly to dramatically altered ecological conditions, together with con- 


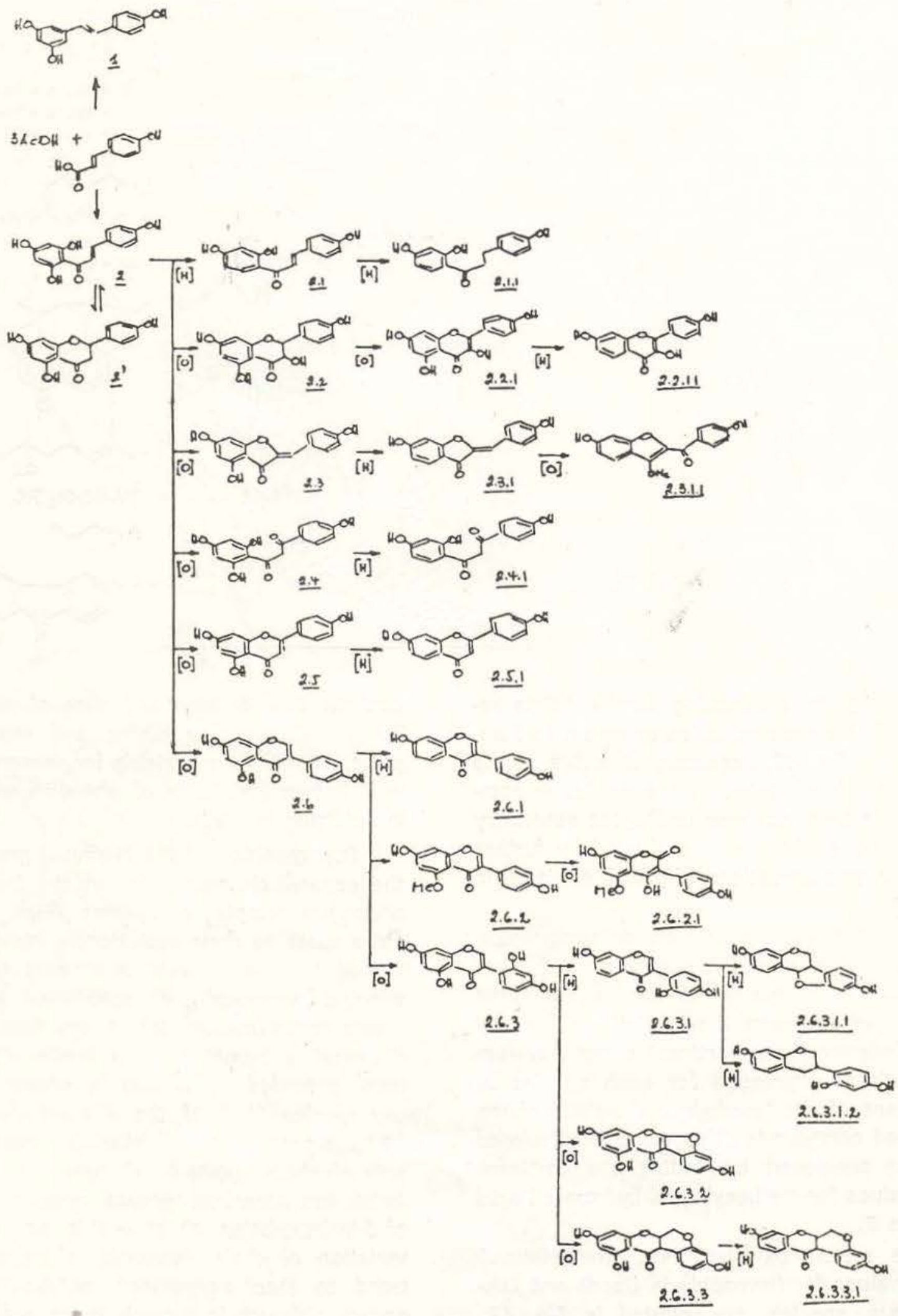

Fig. 15 - Biogenetic Classification and Codes for structural types of Flavonoids from Tephrosieae 
traction of the inflorescence and change to arboreous habit, upon radiation into savanna regions. These phenomena accompany development of the south American species (10-18) of the Lonchocarpus group ( $\mathbf{m}$ ) which must have occurred at relatively recent times, after the separation of the continents and possibly even after the quaternary glaciations.
There is only one major fact which may be evoked against this theory: the distributional gap between the Paraderris and Phacelanthus groups. We do not consider this too disturbing. Rotenoid containing Derris or Lonchocarpus species from Africa may either so far have escaped detection or have succumbed in the Ice Ages. Their (past or present)

TABLE 5 - Increments for the calculation of the "oxidation" value of a flavonoid

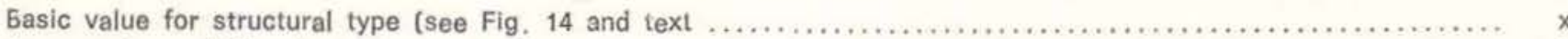

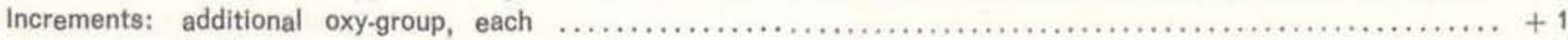

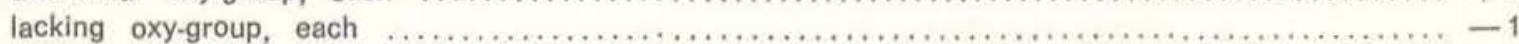

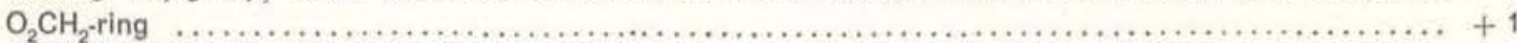

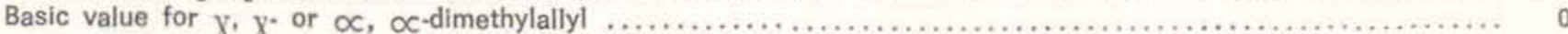

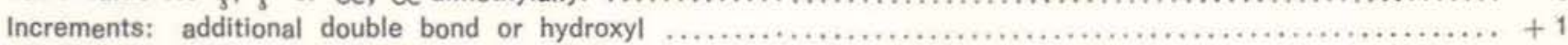

cyclization to dimethylchromene or isopropen yldihydrofurane $\ldots \ldots \ldots \ldots \ldots \ldots \ldots \ldots \ldots \ldots \ldots \ldots+1$

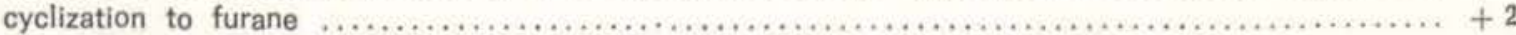

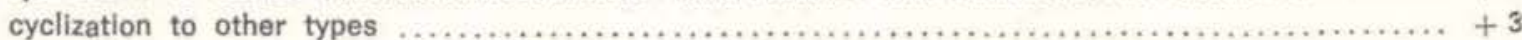

TABLE 6 - Increments for the calculation of the "methylation" value of a flavonoid

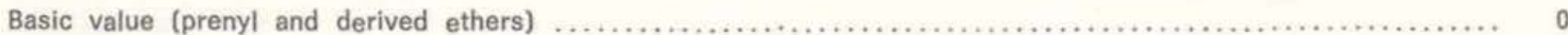

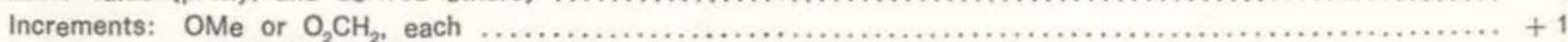

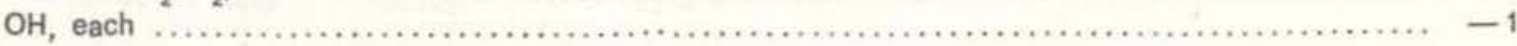

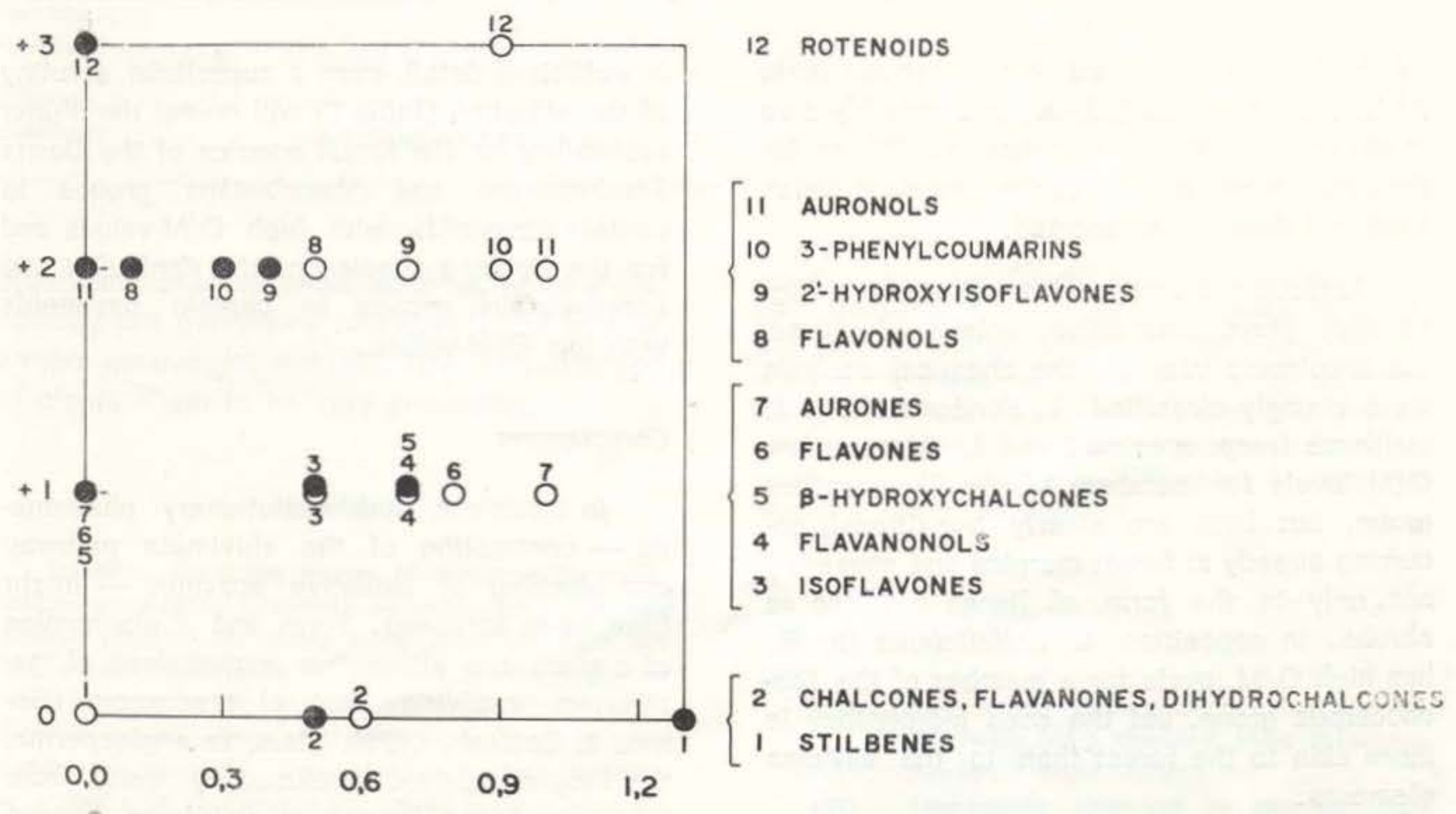

Fig. 16 - Correlation of "oxidation" values of the indicated Flavonoid skeletons (ordinate) with the number of unmodified prenyls $(\bullet)$ and oxidatively modified prenyls (0) per derivative (abscissa). 


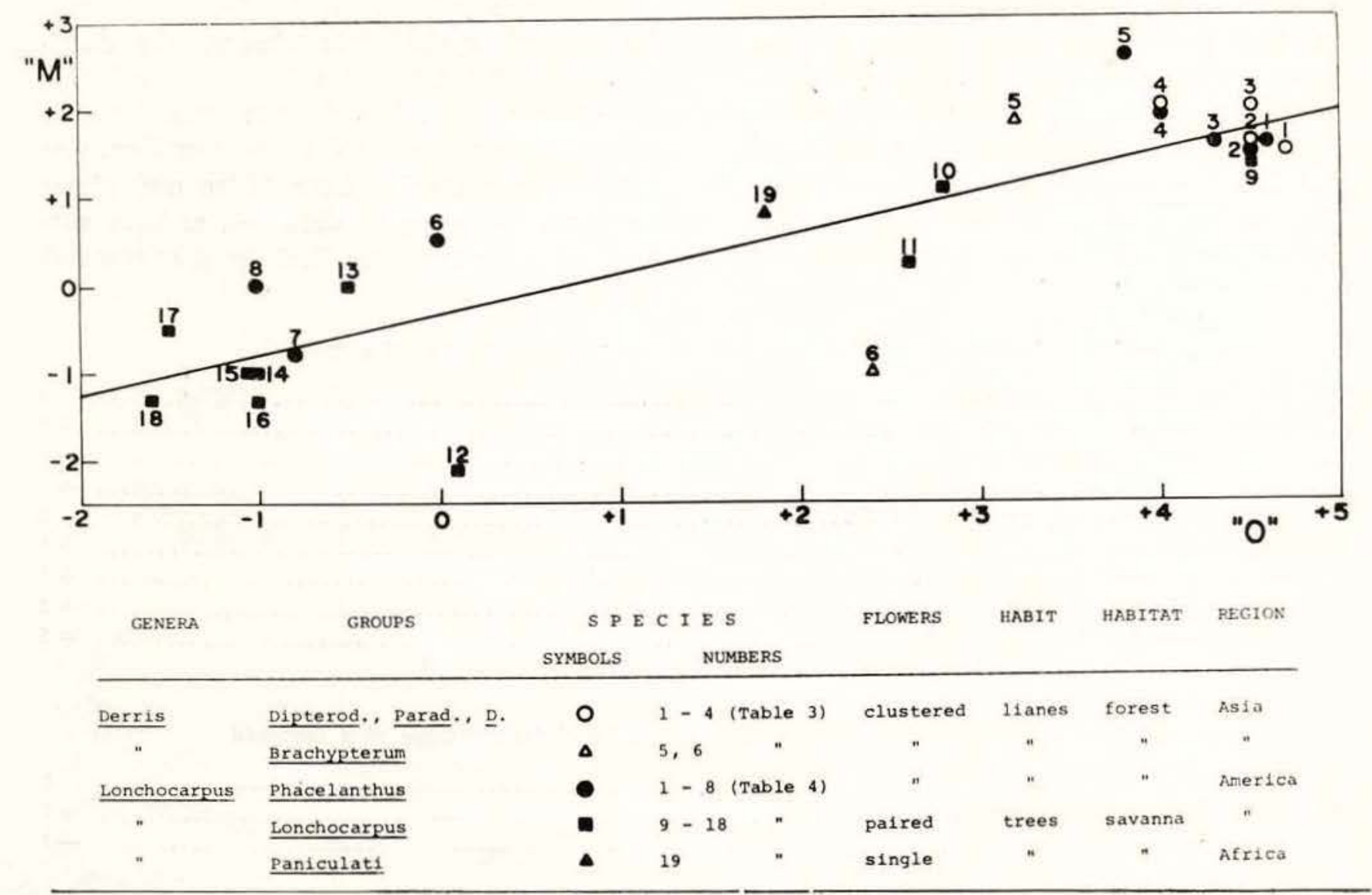

Fig. 17 - Mean "oxidation"/"methylation" $(\mathrm{O} / \mathrm{M})$ values for Flavonoids from Derris-Lonchocarpus species.

existence is documented in the derived west African L. laxiflorus $(19, \mathbf{A})$ and possibly also in the ambi-Atlantic L. sericeus (12, a), so far the sole African species of the genus for which flavonoid data were reported.

Particular discrepancies apparent in Fig. 16 may prove instructive, unless, of course, the specimens used for the chemical analysis were wrongly classified. $L$. floribundus and $L$. rariflorus (resp. species 7 and 8 , ) have low $\mathrm{O} / \mathrm{M}$ levels for members of the Phacelanthus group, but both are clearly transitional, occurring already at forest margins and appearing not only in the form of lianes but also as shrubs. In opposition $L$. unifoliolatus $(9, \mathbf{a})$ has high $\mathrm{O} / \mathrm{M}$ levels for a member of the Lonchocarpus group, but the seed morphology is more akin to the forest than to the savanna elements.

As in the Aniba case, although thus all facts may be understandable only if examined in sufficient detail, even a superficial scrutiny of the situation (Table 7) will reveal the higher probability for the forest species of the Derris Brachypterum and Phacelanthus groups to contain flavonoids with high $\mathrm{O} / \mathrm{M}$-values and for the savanna species of the Paniculati and Lonchocarpus groups to contain flavonoids with low $\mathrm{O} / \mathrm{M}$-values.

\section{Conclusion}

In hindsight, both evolutionary phenomena - contraction of the shikimate pathway and blocking of oxidative enzymes - might have been foreseen. Form and allelochemics of a plant are alternative expressions of metabolism involving identical precursors (Gomes \& Gottlieb, 1978). Thus, in angiosperms, the long recognized evolutionary trend from arboreous forms (based on shikimate derived lignin) to herbaceous forms should indeed be accompanied by the gradual replacement of 
shikimate by acetate or mevalonate derived allelochemics. Should, furthermore, an increase in oxygen uptake be required to power the energy producing process which introduces the modifications associated with the development of a new lineage? If so, once the lineage is established, blocking of oxygen-transferring enzymes is to be expected for reasons of economy and concomitant activation of other, inherited enzyme systems should take place.

Whatever the acceptability of such interpretations, the principles point the way to a unified evolutionary scheme of secondary metabolites on which to base the appraisement of trends in plant evolution. If these trends were to be considered with changes of

TABLE 7 - Number of species of known flavonoid compusit tion belonging to the Derris, Dipteroderris \& Paraderris (DER), Brachypterum (BRA), Phacelanthus (PHA), Paniculati (PHAN) and Lonchocarpus (LON) groc.ps.

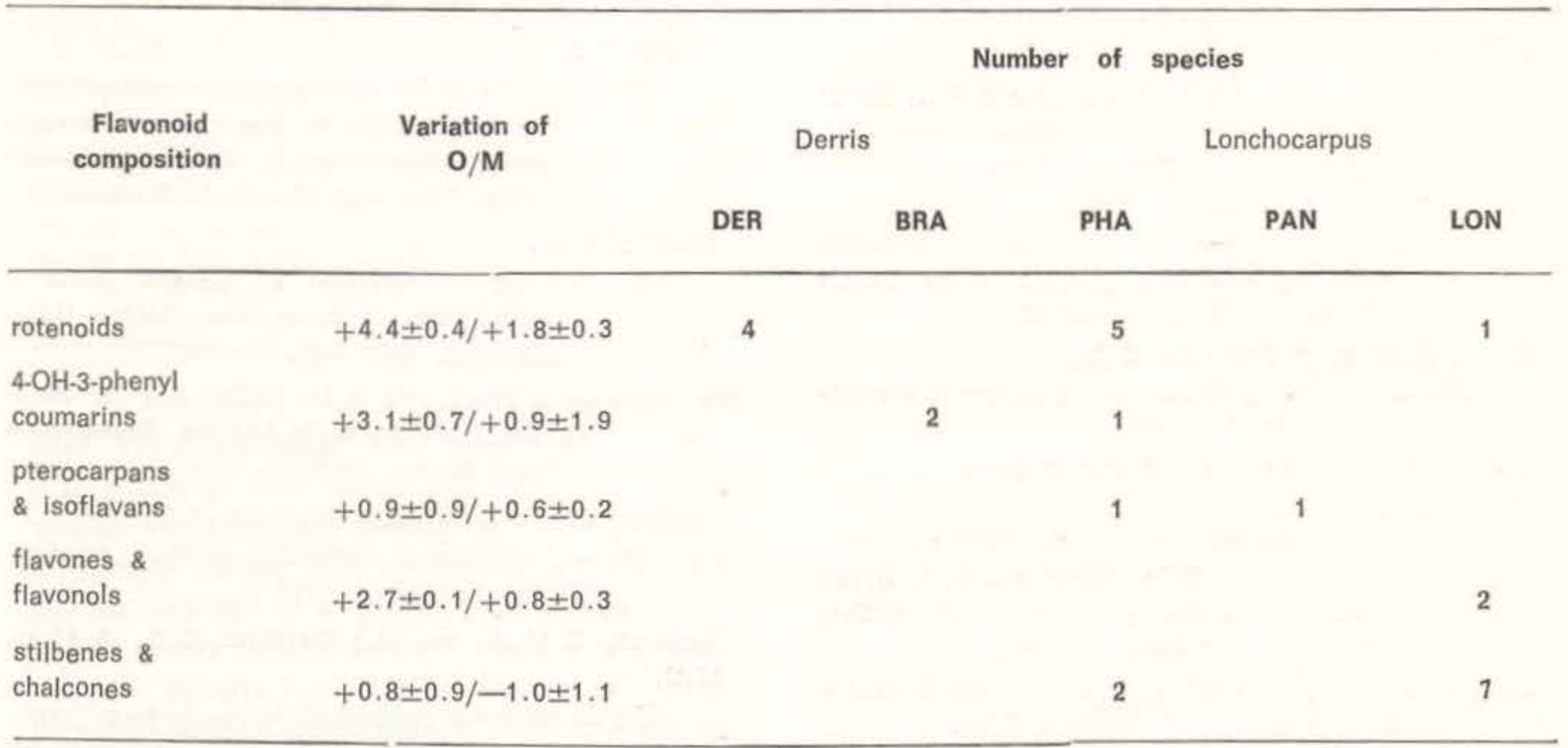

other functional systems, such as morphology ecology and geography, the chances of making a more meaningful and predictive classification of plants seem to be very promising.

\section{Resumo}

Enquanto diferentes grupos biogenéticos de metabolitos secundários raramente se acumulam na mesma espécie vegetal, um grupo pode substituir outro em taxons morfologicamente relacionados. Assim o uso de micromoléculas como marcadores sistemáticos gerais do reino vegetal requer postulados unificadores de seus padrōes de evolução. Dois postulados desta natureza - a contração do caminho do chiquimato e o bloqueio de enzimas oxidativas - são ilustrados com ajuda de considerações sistemáticas acerca dos generos Aniba (Lauraceae) e Derris-Lonchocarpus (Leguminosae) que envolvem, além de química, também morfologia, ecologia e geografia. Parece possivel extrapolar os principios aplicados nestes exemplos a todo o reino vegetal, o que é importante, devido às implicaçōes ecológicas das micromoléculas. Neste sentido, o trabalho abre caminho, não apenas a uma classificação mais "natural", mas ainda a um arquivo de informaçōes de relevância ecológica acerca das plantas.

\section{LITERATURE}

BIRCH, A.J.

1963 - Biosynthetic pathways. pp. 141-166. In: T. Swain (ed.) Chemical Plant Taxonomy. Academic Press, London.

1973 - Biosynthetic pathways in chemical phylogeny. pp. 261-270. In: G. Bendz \& J. Santesson (eds.) Chemistry in Botanical Classification. Academic Press, New York. 
CAGNIN, M.A.H.; GoMes, C.M.R.; GotTlleb, O.R.; MARX, M.C.; ROCHA, A.I. DA; SILVA, M.F. DAS G.F. DA \& TEMPERINI, J.A.

1977 - Biochemical systematics: methods and principles: Plant. Syst. Evol., (suppl. 1): 53-76.

CAGNin, M.A.H. \& GotTlieb, O.R.

1978 - Isoflavonoids as systematic markers. Biochem. Syst. Ecol., 6: 225-238.

Cronguist, A.

1968 - The Evolution and Classification of Flowering Plants. p. 5, London, Nelson.

Ferreira, Z.S.; GotTlieb, O.R, \& Ropue, N.F.

1980 - Chemosystematic implications of benzyltetrahydroisoquinolines in Aniba. Biochem. Syst. Ecol., $8: 51-54$.

GEESINK, A.J.

1980 - In press. In: R.M. Polhill and P.H. Raven (eds.) Advances in Legume Systematics. Royal Botanic Gardens, Kew.

Gomes, C.M.R. \& GotTlieb, O.R.

1978 - The evolution of structural biopolymers and secondary metabolites is connected? Revta. brasil. Bot., 1: 41-45.

Gomes, C.M.R. \& GotTlieb, O.R.

1980 - Alkaloid evolution and angiosperm systematics. Biochem. Syst. Ecol., $8: 81-87$.

Gomes, C.M.R.; GotTlieb, O.R.; GotTlieb, R.C. \& Salatino, A.

1980 - Chemosystematics of the Papilionordeae. In press. In: R.M. Polhill and P.H. Raven (eds.) Advances in Legume Systematics. Royal Botanic Gardens, Kew.

Gcmes, C.M.R.; Gottlleb, O.R.; Marini-Betròlo, G.B.; Delle Monache, F. \& Polhill, R.M.

1980 - Systematic significance of flavonoids in Derris and Lonchocarpus (Tephrosieae). Biochem. Syst. Ecol., 8: in press.

GOTTLIEB, O.R.

1972 - Chemosystematics of the Lauraceae. Phytochemistry, 11:1537-1570.

1980 - Micromolecular systematics: principles and practice. pp. 329-352. In: F.A. Bisby, J.G. Vaughan \& C.A. Wright (eds.) Chemosystematics: Principles and Practice. London, Academic Press.

Gottlieb, O.R.; Gomes, C.M.R.; Salatino, A.; Silva, M.F. DAS G.F. DA \& Young, M.C.M.

1980 - Published in preliminary form In: Memorias del VIII Seminario Latinoamericano de Quimica. Universidade de Buenos Aires.
GotTLIEB, O.R. \& KubITZKI, K.

1980 - Chemosystematics of Aniba (Lauraceae). Biochem. Syst. Ecol., 8: in press.

$1980 \mathrm{~b}$ - Chemogeography of Aniba (Lauraceae). Plant Syst. Evol., 133: (in press).

Kaplan, M.A.C.; Figueiredo, M.R.; SChatchevski, F. \& GotTlieb, O.R.

1980 - Iridoids as systematic markers, Ciência e Cultura, São Paulo, 32(7) : 451 .

KUBITZKI, K.

1980 - Flora Neotropica, to be submitted.

Kubitzki, K. ; Mesquita, A.A.L. \& Gotrlieb, O.R.

1978 - Chemosystematic implications of xantho. nes in Bonnetia and Archytaea. Biochem. Syst. Ecol., 6 : 185-187.

MABRY, T.J.

1974 - Is the order Centrospermae monophyletic? pp. 275-285. In: G. Bendz \& J. Santesson (eds.) Chemistry in Botanical Classification. New York, Academic Press.

POLHILL, R.M.

1971 - Some observation on generic limits in Dalbergiëae-Lonchocarpineae Benth. (Leguminosae). Kew Bull., $25: 259-273$.

1980 - In press. In: R.M. Polhill \& P.H. Raven (eds.) Advances in Legume Systematics. Royal Botanic Gardens, Kew.

Rezende, C.M.A. DA M. \& GotTlieb, O.R.

1973 - Xanthones as systematic markers. Biochem. Syst. Ecol., 1 : 111-118.

Rezende, C.M.A. DA M.; Gottlieb, O.R. \& MarX. M.C.

1975 - Benzylietrahydroisoquinoline-derived alkaloids as systematic markers. Biochem. Syst. Ecol., 3:63-70.

Salatino, A. \& Gottlieb, O.R.

1980 - Quinolizidine alkaloids as systematic markers of the Papilionoideae. Biochem. Syst. Ecol., 3: 133-147.

SMrTH, P.M.

1976 - The Chemotaxonomy of Plants. London, Edward Arnold, p. 313.

(Aceito para publicação em $5 / 11 / 80$. Prioridade autorizada). 